\title{
Local Government Debt and Municipal Bonds in China: Problems and a Framework of Rules
}

\author{
XINGYUAN FENG
}

\begin{abstract}
Local governments in China are facing heavy debt burdens, a low level of fiscal transparency and a lack of constraints by local democracy. Since 2008, local government debts have skyrocketed. This article analyses the current state and features of local government debts and the two kinds of 'quasi municipal bonds' in China - urban investment bonds and local government bonds - along with their problems and risks. It examines the risks connected with local government debts and these bonds from the perspectives of public finance and political economy. It concludes with a discussion of a framework of rules for local government debt financing, especially for the issuance of municipal bonds in China.
\end{abstract}

Keywords: local government debt, urban development bonds, local government bonds, local government financing vehicle companies, municipal bonds, China

\section{Introduction}

Administrative and fiscal decentralization in the early 1980s led to the formation of strong local political interests and to a certain degree of regional and local autonomy with relatively hard budget constraints for local governments (Herrmann-Pillath and Feng 2004; Jin, Qian and Weingast 2005). ${ }^{1}$ However, it took place under a system of authoritarian government, including both the central government and local governments. The decentralization gave rise to fierce competition among local governments in China (Li, Li and Zhang 1998; Feng 2010). And the close link between local government revenue and expenditure provides strong incentives for local governments to drive local economic development. Although China is formally a unitary system, government behaviour can be well described by employing a 'competitive governments' paradigm (Breton 1996; Herrmann-Pillath 1999; Herrmann-Pillath and Feng 2004) or a 'competitive authoritarianism' paradigm (Levitsky and Way 2013). ${ }^{2}$

Local state developmentalism has led to rapid industrialization and urbanization across China, which have progressed at breakneck speed 
since 1996. During both processes, local governments have been faced with increased financial pressure and a widening gap between revenue and expenditure. Accordingly, local governments, especially at the city and county level, have faced continually increasing debts. This problem became much more serious after a rapid expansion of local government debt took place with the central government's launch of the stimulus package in 2008. It has caught the attention of the government and society. More and more people are looking at problems of near unrestrained debt financing behaviour, low fiscal transparency and high fiscal risks of local governments. 'Municipal bond' issuances as part of actual or hidden local government debts have become increasingly visible. The enforcement of a suitable framework of rules regulating local debt financing, including 'municipal bond' issuance, has become necessary in this situation.

Almost without exception, the existing literature on local government debt in China mainly deals with the size, growth, causes and risks of local government debt. However, because of the adoption of a proactive debt financing strategy never seen before and encouraged by the central government, as well as the rapid increase in the size of local government debt since 2008, the literature on the empirical assessment of the level of fiscal risks of local governments prior to that year has become less relevant. Given the lack of transparency of local debt financing, up-to-date and in-depth empirical studies are still in the early stages, mainly focusing on some particular dimensions of local government debt. For instance, He and Man (2011) assess the size, growth, causes and risks of interest-bearing debts of local government investment and financing vehicle companies of Chinese provinces. Their study shows that the fiscal risks in some provinces are relatively high in terms of the ratio of debt balance to local budgetary revenue. However, the assessed debt constitutes only a part of local government debt, thus an incomplete reflection of the overall situation of debt financing of local governments. Yu and Wei (2012) estimate the total size of government debt in 2010. Lu (2012) analyses quite systematically the problems of local government vehicle companies in China. As a supplement to the empirical assessments, additional analyses are made from a political economy perspective. Brenan and Buchanan $(1980,1985)$ elaborate on government behaviour with self-interest maximizing models and derive some necessary constitutional rules for 'taming' the government from a theoretical perspective of constitutional economics. Feng and Li (2005) and Zheng (2012) adopt such a perspective to elaborate the self-interest 
oriented 'leviathan' features of local governments in debt financing in China and problems with the lack of democracy and fiscal surveillance, and identified their negative effects on the private sector development of local China. ${ }^{3}$ In summary, there is still a lack of a balanced analysis of the local government debt and the issuance of 'municipal bonds' from both the political economy and public finance perspectives. Without such an analysis, we are less likely to get deep insights into the problems of local government debt and to identify rules regulating local governments' debt financing behaviour.

This article is an effort to help meet the need for research that combines the above mentioned two perspectives. In the following, the author first makes a more concrete assessment of the current state and problems of local government debt in China based on available data, focusing on the characteristics and functioning of the existing two types of local government debt bonds, i.e. 'urban investment bonds' (cheng tou zhai) and 'local government bonds' (difang zhengfu zhai), ${ }^{4}$ which are similar to municipal bonds in the Anglo-American context but deviate from them to some degree. The article also looks at problems with the regulatory framework currently in place for the management of local government debt, especially the issuance of these debt bonds. The article concludes with a discussion of a framework of rules to regulate local government debt financing, including the issuance of municipal bonds of the typical types prevailing in some developed economies such as the USA.

\section{Local Government Debt in China: The Current Situation}

There are a number of different definitions of local government debts in China. The first is a narrow one: actual government debt when total expenditure exceeds total revenue of local governments. Therefore, local government debt can be interpreted as the difference between the total local expenditure and the total local revenue of a local government, where the total local expenditure includes the budgetary, extra-budgetary and system-external expenditures and total local revenue includes the budgetary, extra-budgetary and system-external revenues. ${ }^{5}$ This definition includes many types of debts, such as government loans from businesses or banks, short-term inter-governmental loans, debts owed to construction companies or teams for public works projects, etc.

However, local governments in China must also take on the debt for projects of companies that are directly or indirectly under them. Therefore, a broader definition of government debt should also include part 
or all of such debt. Unless otherwise stated, local government debt in China in this article should be understood in the context of this second, broader definition.

The 'Budget Law' of China explicitly provides that

Local budgets at various levels shall be compiled according to the principles of keeping expenditure within the limits of revenue and maintaining a balance between revenue and expenditure, and shall not contain deficits. Except for where provided by law or State Council regulation, local governments shall not issue local government debt bonds. (Article 28)

The 'General Lending Provisions' and 'Guarantee Law' of China also prohibit local governments from taking loans from banks. However, local governments deal with deficit financing through their projects or companies, or some subordinate public institutions such as public schools or hospitals and are able to find ways to issue openly or covertly, directly or indirectly, a large amount of debt and this phenomenon has become increasingly common. The whole process lacks transparency. The debt financing problem has become more serious since 2008 with the global financial crisis, when the central government released a 4 trillion RMB stimulus package and allowed local governments to engage in deficit financing proactively by taking out large loans from banks to invest mainly in infrastructure projects. This set the stage for the emergence of a large number of local financing vehicle companies (difang rongzi pingtai gongsi, hereafter referred to as 'financing vehicle companies') connected to local governments.

Statistics from the China Banking Regulatory Commission show that as of May 2009, there were 8,221 financing vehicle companies at the provincial, prefecture and county levels registered in China. Of these, 4,907 were registered at the county level. The 2010 Report on Regional Financial Operations of the People's Bank of China shows that by the end of 2010, there were over 10,000 financing vehicle companies established by local governments, up 25 per cent over 2008. Of these financing vehicle companies, 70 per cent were at the county level or below. According to the audit report of the National Audit Office (2011), there were in total 6,576 financing vehicle companies at the provincial, prefecture and county level in 2010.

These financing vehicle companies have been quickly established by local governments through the allocation of land, equity shares, fees and national bonds and have a level of capital or cash flow that allows them to carry out financing. When needed, they can also act to supplement funds from general fiscal revenue and land revenue, and even provide 
direct or indirect government credit guarantees. These companies use various methods to bring financing capital into their regions, then transfer it to public enterprises or institutions for projects of varying degrees of profitability, including urban infrastructure projects.

Financing vehicle companies usually appear as urban construction investment companies (chengtou gongsi). They may also be called 'urban development' and 'urban financing' companies. The operational structure of financing vehicle companies is shown in Figure 1. These companies are always fully owned or controlled by local governments. Some are even listed on stock exchanges. Local governments use land transfer revenue, fiscal subsidies or even government credit as guarantees for financing vehicle companies looking to obtain loans, or issue 'urban investment bonds' to financial organizations or other investors on securities markets. These financing vehicle companies then take the funds that they have collected and invest them in urban construction projects. However, these projects often cannot repay the loans that fund them. The responsibility for repaying these loans thus falls on the local governments, which implies that if a large-scale debt crisis emerges, the ones ultimately responsible are taxpayers at the local level or possibly even at the national level.

Under this backdrop, debt accumulated by financing vehicle companies continues to grow. The 2010 data deserves special attention since

FIGURE 1: Operating Model of Local Government Financing Vehicle Companies

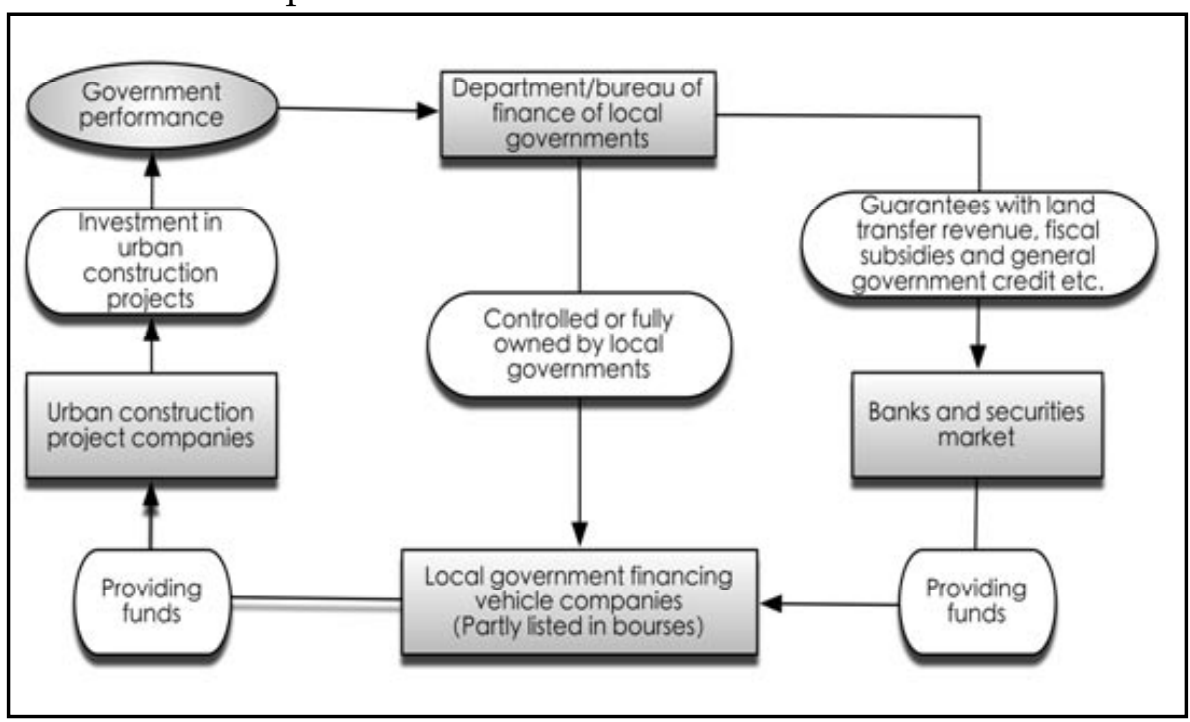

Source: The author. 
several sources revealed different data for the first time. Based on the comparison between them, one can estimate the overall debt size of local governments or even the whole government system more precisely than before.

Figure 2 shows the scale of interest-bearing debt held by the 340 of these companies that issued urban investment bonds in China from 2006 to 2009. These data include short- and long-term loans, interest payable and bonds payable held by them. The size of interest-bearing debt of these companies increased rapidly from RMB 4.79 trillion in 2008 to RMB 7.97 trillion in 2009, reflecting the central government's new policy of encouraging local governments' deficit financing through their financing vehicle companies.

FIGURE 2: Amount of Interest-bearing Debt Held by Financing Vehicle Companies (2006-2009)

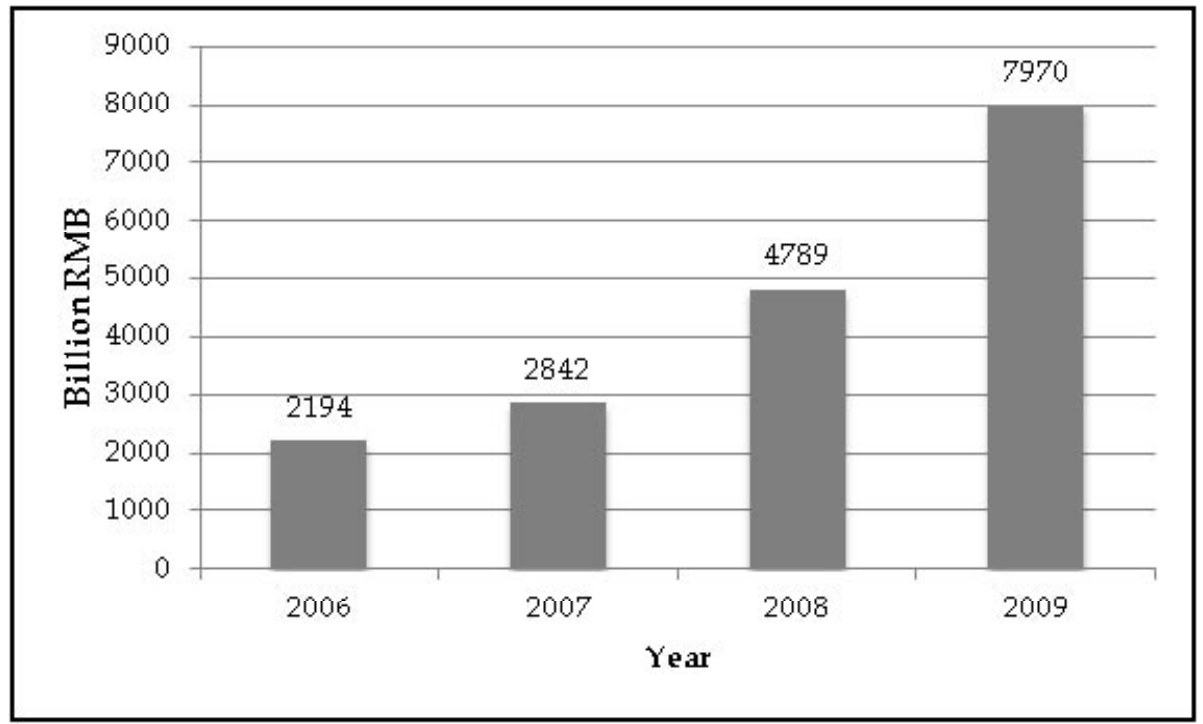

Source: He and Man (2011).

Local governments' debt financing levels have increased rapidly up to now. Figure 3 shows the incomplete size of local governments' direct debt, revealed by various government departments. It increased from RMB 8.3 trillion in 2010 to RMB 11.4 trillion in 2012. According to the data revealed by the China Banking Regulatory Commission, bank loans alone held by financing vehicle companies amounted to RMB 9.2 trillion by the end of 2012 (Netease Finance 2013a), while the debt balance of urban investment bonds, mid-term notes and short-term financing notes, private targeted financing instruments, and asset-backed notes of financing vehicle companies reached RMB 2.5 trillion (Zhang 2013). 
This does not include the direct debt held by government departments, construction project companies, units for public services such as public schools and hospitals, and payables for construction teams or companies.

FIGURE 3: Amount of Direct Debt of Local Governments (2010-2013)

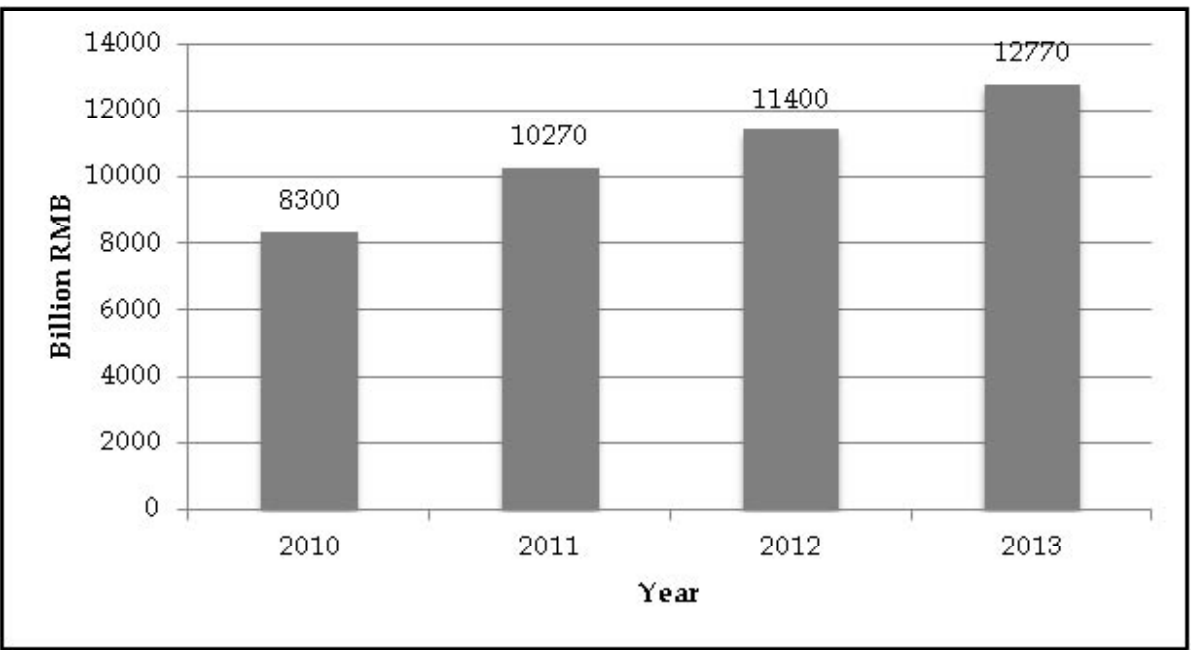

Note: The 2010 data includes the direct debt held by all financing vehicle companies audited by the National Audit Office (2011). The data of 2011-2013 are revealed or predicted by the State Asset Supervision and Administration Commission (Yang 2013). These government departments reported only a narrowly defined debt size of a part of vehicle companies, while the debt size of the remaining part has been kept hidden resulting in an underreporting of the actual direct debt size of vehicle companies. Therefore, the data in Figure 3 are incomplete. Sources: National Audit Office (2011); Yang (2013).

In the following, we can estimate the total debt of local governments in China at the end of 2012. The total amount of direct and indirect debt held by local governments was at least RMB 25.11 trillion, or 48.35 per cent of GDP at the end of 2012 (Table 1). Out of this, the total balance of loans for financing vehicle companies was RMB 9.2 trillion, according to the China Banking Regulatory Commission (Shi 2013). According to the calculation based on the databank provided by Wind Financial Information System, the total debt balance of urban investment bonds, midterm notes, short-term financing notes, private targeted debt financing instruments and asset-backed notes was RMB 2.5 trillion (Zhang 2013). Because of the strict regulations of the China Banking Regulatory Commission and the Securities Commission, local governments increasingly rely on funds from trust fund borrowings, which are off-balance-sheet, and often request repurchase agreements as repayment guarantees. According to the China Trust Business Association, the balance of trust fund borrowing totalled RMB 0.5 trillion at the end of 2012 (Xu 2013). 
The amount of borrowing by non-vehicle government project companies or public units can be estimated to be at least RMB 3 trillion, given that many project companies of all levels not only use funds transferred by financing vehicle companies, but also borrow funds directly from banks and other sources. This is a low estimate by the author. The ratio of the narrowly defined debt balance of financing vehicle companies to the debt balance of local government departments and institutions in the 36 jurisdictions at various levels that were audited by National Audit Office (2013) was 1.8:1 at the end of $2012,{ }^{6}$ which is much lower than $3: 1$, the underlying ratio of China as a whole adopted here. This also implies that non-vehicle borrowing could eventually reach around half of the direct debt of financing vehicle companies across China, i.e. as high as around RMB 5 trillion. The total payables for construction companies or teams or other units, and the balance of contingent debt can be estimated to be at least RMB 3.04 trillion for both, if taking only 20 per cent of the above sum of direct debt as the basis for estimation. Hidden debt related to retirement insurance totalled RMB 2.23 trillion. ${ }^{7}$ The balance of local government bonds (difang zhengfu zhaiquan) was RMB 650 billion at the end of 2012, according to Ministry of Finance statistics. Township-level government liabilities totalled RMB 830 billion in 2010 (Yu and Wei 2012). We take this figure as the estimated debt size of township-level governments at the end of 2012, while at the village level, the direct debt is estimated as RMB 120 billion. Villages are not legally governments, but here their function and operation is similar to self-governing entities as seen as in the West. According to the report of the Team of the Project on 'Research on Problems with County and Township Level Government Finance in China' (2005), the average net debt balance of each village was RMB 200,000 in 2002. The number of administrative villages was over 600,000 in 2012, according to the Ministry of Civil Affairs. Taking this average debt size as the base and disregarding the growth rate and a reduction in the number of villages through mergers, the total village net liabilities are estimated to be at least RMB 120 billion in 2012.

For comparison, Standard Chartered (2013) estimated the current amount of the outstanding debt of financing vehicle companies is in the range of RMB 14-15 trillion, some 30 per cent of Chinese GDP at the end of 2012. Our estimate of the debt is larger. Such a comparison is not very meaningful since it is unclear how Standard Chartered defines local government debt in China. 
TABLE 1: Estimates of Local Government Liabilities in China at the End of 2012 (in trillion RMB)

\begin{tabular}{|c|c|c|c|}
\hline Type of Liability & Amount & Scope & Description \\
\hline $\begin{array}{l}\text { Total loans of financing } \\
\text { vehicle companies }\end{array}$ & 9.2 & Direct debt & $\begin{array}{l}\text { Data provided by the China } \\
\text { Banking Regulatory Com- } \\
\text { mission (Shi 2013). }\end{array}$ \\
\hline $\begin{array}{l}\text { Total debt balance of urban } \\
\text { investment bonds, mid-term } \\
\text { notes, short-term financ- } \\
\text { ing notes, private targeted } \\
\text { financing instruments and } \\
\text { asset-backed notes of financ- } \\
\text { ing vehicle companies }\end{array}$ & 2.5 & Direct debt & $\begin{array}{l}\text { Calculation based on Wind } \\
\text { Financial Information } \\
\text { System (Zhang 2013). The } \\
\text { balance of urban invest- } \\
\text { ment bonds and mid-term } \\
\text { notes is RMB } 1.44 \text { trillion (Li } \\
\text { 2013). }\end{array}$ \\
\hline $\begin{array}{l}\text { Trust fund borrowings } \\
\text { (xintuo zijin) of local govern- } \\
\text { ments }\end{array}$ & 0.5 & Direct debt & $\begin{array}{l}\text { Statistics of China Trust } \\
\text { Business Association (Xu } \\
\text { 2013); including those of } \\
\text { financing vehicle companies } \\
\text { and local government de- } \\
\text { partments and institutions. }\end{array}$ \\
\hline $\begin{array}{l}\text { Other borrowings of local } \\
\text { government departments or } \\
\text { institutions }\end{array}$ & 3.0 & Direct debt & Low estimate by author. \\
\hline $\begin{array}{l}\text { Payables of local govern- } \\
\text { ments for construction } \\
\text { companies or teams }\end{array}$ & 3.04 & Direct debt & $\begin{array}{l}\text { Low estimate of around } \\
20 \% \text { of the above total direct } \\
\text { debt of local governments. }\end{array}$ \\
\hline $\begin{array}{l}\text { Contingent debt held by } \\
\text { local governments }\end{array}$ & 3.04 & $\begin{array}{l}\text { Contingent } \\
\text { debt }\end{array}$ & $\begin{array}{l}\text { Hidden guarantees by local } \\
\text { government, low level of } \\
\text { estimation of } 20 \% \text { of the } \\
\text { above total debt of local } \\
\text { governments excluding the } \\
\text { payables. }\end{array}$ \\
\hline $\begin{array}{l}\text { Hidden debt related to } \\
\text { retirement insurance }\end{array}$ & 2.23 & Hidden debt & Wang (2013). \\
\hline Local government bonds & 0.65 & Direct debt & Ministry of Finance data. \\
\hline $\begin{array}{l}\text { Estimated township-level } \\
\text { government debt }\end{array}$ & 0.83 & $\begin{array}{c}\text { Direct or con- } \\
\text { tingent debt } \\
\end{array}$ & Yu and Wei (2012). \\
\hline Estimated village liabilities & 0.12 & $\begin{array}{c}\text { Direct or con- } \\
\text { tingent debt }\end{array}$ & Author's estimate. \\
\hline Total & 25.11 & & \\
\hline Percentage of GDP & $42.35 \%$ & & \\
\hline
\end{tabular}

Source: China Banking Regulatory Commission; China Trust Business Association; Li (2013); Ministry of Finance; Wang (2013); Xu (2013); Yu and Wei (2012); Zhang (2013); and author's estimates. 
Table 2 estimates the total debt held by the central government and local governments in China, which is around RMB 44.89 trillion, taking 86.44 per cent of GDP at the end of 2012. This does not include contingent liabilities held by the central government. For comparison, the International Monetary Fund (IMF; 2013)) released an estimate of the total 'augmented debt' of the Chinese government, including the central government and local governments, which totalled nearly 50 per cent of China's GDP in 2013. Fewer forms of government debt are included in the definition of the 'augmented debt'. According to the IMF's explanation, augmented government debt not only includes the debt of a general government, but also

captures borrowing by LGFVs [local government financing vehicle companies] through market financing channels. As in other countries, it excludes liabilities of regular SOEs and other state entities as well as contingent liabilities, such as NPLs in the banking sector, policy bank loans, and pension liabilities. At the same time, it measures gross debt only, and so excludes government assets. (IMF 2013)

TABLE 2: Estimated Debts of Central and Local Governments in China at the End of 2012 (in trillion RMB)

\begin{tabular}{|l|c|l|}
\hline Type of Debt & Amount & Description \\
\hline Local government debt & 25.11 & See Table 1 \\
\hline Central government domestic debt & 7.67 & Ministry of Finance statistics \\
\hline Central government foreign debt & 0.08 & Ministry of Finance statistics \\
\hline $\begin{array}{l}\text { Central government policy finan- } \\
\text { cial bonds }\end{array}$ & $7.84^{1}$ & $\begin{array}{l}\text { China Urban and Rural Fi- } \\
\text { nance Daily (2012) }\end{array}$ \\
\hline $\begin{array}{l}\text { Central government debt related } \\
\text { to the transfer of non-performing } \\
\text { loans to asset management com- } \\
\text { panies }\end{array}$ & 1.4 & Yu and Wei (2012) \\
\hline Department of Railways liabilities & 2.79 & Netease Finance (2013b) \\
\hline Total government debt & 44.89 & \\
\hline Percentage of GDP & $86.44 \%$ & \\
\hline
\end{tabular}

Note: ${ }^{1}$ This amount is the balance to 24 December 2012.

Sources: China Urban and Rural Finance News (2012); Ministry of Finance; Netease Finance (2013b); Yu and Wei (2012); and estimates included in the previous table.

\section{Characteristics and Problems of Local Government Debt}

While there are currently many types of local government debt, there are two rough categories that can be identified based on levels of local government activity in debt financing. The first is active debt financing, which comes from the need for capital to fund local construction 
and economic development. The other is passive debt financing due to excessive fiscal pressure, leaving governments without any other choice but to borrow money and go into debt. This also includes other passive liabilities caused by the bankruptcy of state-owned enterprises, losses from guaranteed projects and the take-over by local governments of financial repayment responsibilities. There are essential differences in their causes, characteristics and impact on the local economy. The first type is a general liability and can have a positive impact on the local economy. This type of liability can be standardized in the form of municipal bonds. However, the second type is incurred due to hidden deficits and bad debts. This should not be replaced by issuing municipal bonds.

In general, local government debt has the following characteristics:

1. The overall debt level of local governments is already very high and will further increase in the coming years. The total amount of the debt balance of local governments rose rapidly after 2008 and reached a record high of 42.35 per cent of Chinese GDP at the end of 2012, as shown in Table 1. According to the estimate by the National Audit Office (2011), which encompasses only a narrowly defined debt size of a part of vehicle companies, local governments' ratio of total debt balance to their total regular budgetary revenue was 70.45 per cent across the whole country, and it even exceeded 100 per cent in 78 prefecture-level cities and 99 counties (or county-level cities or districts) at the end of 2010. The ratio of direct debt to the consolidated local budgetary revenue (including fiscal transfer) of 10 out of 36 audited local governments exceeded 100 per cent at the end of 2012, with 188.95 per cent as the highest ratio (National Audit Office 2013). The central government and local governments have not taken measures to reduce debts, and they have kept expanding their spending, so that the overall trend will be a further rise in the debt levels of local governments.

2. The debt levels differ significantly from one region to another. According to He and Man (2011), the levels of total interest-bearing debt of financing vehicle companies of Chinese provinces differed widely in 2009: the ratio of total debt balance of financing vehicle companies to local governments' total regular budgetary revenue ranged from 0.11 in Guizhou province to 12.42 in Jiangsu province.

3. The debt structure is multi-levelled and complex. This is mainly due to remaining historical issues and the many reforms that have been implemented over the past nearly two decades. Local gov- 
ernment debts can be grouped into six categories based on their characteristics (Fan et al. 2001; He and Man 2011; Wang 2013). The six categories are:

a. Debts held by local governments, their functional departments and associated entities for public services such as public schools and hospitals. This includes loans from international financial organizations, on-lending funds raised by the Ministry of Finance by issuing treasury bills (guozhai zhuan dai zijin), local government bonds issued by the Ministry of Finance on behalf of local governments or by local governments themselves, loans from domestic financial institutions and loans from other units or individuals;

b. Debt guaranteed directly or indirectly by local governments;

c. Dead debt caused by losses incurred by local governmentowned companies such as grain companies, or payables of local governments such as unpaid salaries and benefits, and outstanding payments for local government procurements;

d. Debt not directly owed by local governments, but by local government-owned trust and investment companies, banks, or local financing vehicle companies;

e. Debt resulting from failed local state-owned enterprises and the take-over by local governments of financial repayment responsibilities such as the case of local government closing down Rural Cooperative Funds (nongcun hezuo jijinhui) by order of the central government in 1999;

f. Hidden debt related to retirement insurance.

Categories $c$, e and finvolve passive debt financing. Other categories are involved with both active and passive debt financing.

4. The funds raised are mainly used for local construction projects. Of the local spending of RMB 3, 643.4 billion audited by the National Audit Office (2013), 92.14 per cent was used for construction projects in transport, public utilities, education, culture, science, healthcare, agriculture, water conservation, environmental protection, affordable housing, and land take and reserve.

5. More and more debt is raised through financing vehicle companies, especially by taking bank loans and issuing urban investment bonds. The total amount of local government bonds issued by the Ministry of Finance on behalf of local governments and by several local governments themselves as pilot measures has also increased. According to the National Audit Office (2013), 78.07 per cent of the 
debt balance of the audited 36 local governments was loans, and 12.06 per cent was bonds at the end of 2012 .

6. Debt financing was discouraged by the central government before the outbreak of the global financial crisis, explicitly encouraged by the central government in $2009,{ }^{8}$ and tolerated by it to maintain a strong stimulus to the economy. However, some measures were taken to control fiscal risks related to local government debt, mainly by standardizing the operations of financing vehicle companies and strengthening the loan control and the control of issuance of urban investment bonds. ${ }^{9}$ However, both loan balances and amount of urban investment bonds keep increasing. Local governments also resort to other types of financial services, such as off-sheet financial services of banking institutions and trust products to meet their demand for additional funds. In addition, the central government imposed upon local governments the task of building 36 million apartments for low-income people in the framework of the government's affordable housing programme across China within the 12th planning period (2011-2015). This has led to greater fiscal pressure on local governments and the necessary tolerance by the central government of local governments' debt financing on a vast scale.

The following problems can be identified with the debt financing of local governments:

1. There is a lack of transparency in local governments' debt financing. During the period prior to the mid-1990s, when fiscal affairs were managed independently, local debt was mainly comprised of open debts like unpaid accounts, the issuing of bonds and bank loans. Since the implementation of the Budget Law, released in 1994, a large part of debt has become hidden or contingent. In recent years, not only has open debt greatly increased, hidden debt has also steadily risen. For example, loans and financing through financing vehicle companies since 2008 are a type of open debt. Hidden debts mainly include contingent liabilities and unpaid costs such as salaries, work expenses, venue costs, roadways and bridges.

2. A part of the debt is not fully covered by guarantees or collaterals (He and Man 2011; National Audit Office 2013). In addition to the debts of financing vehicle companies, some guarantors provide guarantees for debt held by other companies. If there is a default with these other companies, the real value of the guarantees provided for the debt held by a vehicle company will be affected. There are also often cases where the same collateral (for instances the use 
right of a piece of land) is repeatedly provided to back several debts owed to different creditors (so-called yi wu duo ya).

3. The assets of a significant part of financing vehicle companies are relatively poor and the registered capital of many financing vehicle companies is insufficient, unlawfully paid in, partly falsified or partly diverted for other uses. By the end of 2012, out of the 223 financing platform companies of the 36 audited local governments, there were 94 companies possessing assets of RMB 897.592 billion that are not or not easily realizable, accounting for 37.60 per cent of their total assets. Of these, five have registered capital of RMB 56.19 billion that is not in place; six companies reported assets amounting to RMB 37.107 which did not exist; and local governments of three provincial capital cities injected unqualified capital totalling RMB 4.553 billion in the form of parks, roads and other public assets (National Audit Office 2013). Around one sixth of all the financing vehicle companies had problems related to false or insufficient capital registration or improper use of registered capital in 2010 (Nie 2013). Taking Liaoning province as an example, in over one third of the 184 financing vehicle companies in that province, part of their registered capital was false in 2010, and the income of 100 of them was insufficient to cover the repayment of debt and interest in the same year ( $\mathrm{Li} 2011)$.

4. It is pervasive that local governments provide indirect or implicit guarantees for the debt repayment or provide some subsidy in case of a default with a local government-related debt (Cao 2013; Yang 2013).

5. The repayment of local government debt relies heavily on land transfer revenue and new borrowings and the repayment pressure is considerable (National Audit Office 2011, 2013). According to the National Audit Office (2011), local governments of 12 provinces, 307 cities and 1,131 counties guaranteed repayment of 37.96 per cent of the assessed local government debt from their land transfer revenue in 2010. Of the debt payable in 2010, 54.65 per cent was repaid from funds raised by new borrowings. According to the National Audit Office (2013), at the end of 2012, the ratio of direct debt repayments to consolidated local budgetary revenue (including fiscal transfer) of the audited governments of 13 provincial capital cities exceeded 20 per cent, with 38.01 per cent as the highest ratio at the end of 2012; the debt/asset ratio of 68 of the above-mentioned 223 financing vehicle companies of the 36 local governments exceeded 70 per 
cent. Furthermore, the income of 151 out of the 223 financing vehicle companies was insufficient to repay the principal and interest due in 2012. According to the National Audit Office (2011), the period of 2012-2013 was the beginning of the peak period for local debt coming into repayment. The total debt to be repaid by financing vehicle companies should have been at least RMB 1.84 trillion in 2012 and will be at least RMB 1.22 trillion in 2013. This is a huge challenge for these financing vehicle companies.

6. The default rate has been increasing since 2010. According to the National Audit Office (2011), one fifth of the 6,500 financing vehicle companies on its list registered a loss at the end of 2010. Some defaults occurred already in 2010. The default rate of local governments in four prefecture-level cities and 23 counties exceeded 10 per cent. According to the National Audit Office (2013), the default rate relating to the repayments of the consolidated debt (including direct debt, guarantees and other related debt) of the above mentioned 36 audited local governments was 0.75 per cent at the end of 2012, up 0.48 of a percentage point from 2010. The default rate of the governments of two audited provincial capital cities exceeded 10 per cent, with the highest reaching 16.36 per cent at the end of 2012. According to the National Audit Office (Nie 2013), the ratio of repayments based on new borrowing exceeded 55 per cent among 358 out of the more than 6,500 financing vehicle companies, and the default rate of around 150 exceeded 16 per cent in 2011. Such repayment arrangements are almost a synonym for hidden defaults. Consequently, news reports on defaults that took place in 2012 are just the tip of the iceberg. ${ }^{10}$

7. There is a lack of effective control by both of the central government and local citizens of local governments' debt financing behaviour that is characterized by a continuous expansion of the debt size with accumulating fiscal and financial risks.

Apart from some technical problems, a large share of the above-mentioned problems can be traced back to a series of institutional shortcomings in the governmental system of China.

1. There is a lack of local democracy in fiscal decision-making, including decisions on debt financing and in the management and supervision of fiscal affairs. The power of local governments is not restricted by local citizens, but rather selectively restricted by the central government that is facing a problem of asymmetric information in its supervision of local governments' behaviour. 
2. Chinese local party and government leaders are appointed rather than actually elected, so they are more responsible to the upper level of party organs and government than to local citizens. ${ }^{11}$

3. In general, one of the most important criteria to measure the performance of local government leaders is still the economic performance of their jurisdictions (Figure 1), and good economic performance in terms of a high GDP growth rate is essential for their careers. ${ }^{12}$ Investment in infrastructure is a key factor in attracting investment in local industries. ${ }^{13}$

4. The term of office of local government leaders is five years and they are not liable for the debt repayment after their leave.

5. Fiscal revenue has been centralized since the 1994 fiscal reform, which leads to strategic actions by local governments, including the large-scale sale of land use rights and deficit financing. The 2008 global financial crisis allowed more leeway for local governments to raise more debt.

The above analysis shows that the fiscal and financial risks have been mounting. It would be fatal to underestimate their threat to fiscal and financial stability in China. This partial loss of control has brought about and exacerbated debt and could lead to widespread financial crises that are already brewing. The new borrowings used for old debt repayments and the defaults that have occurred up to now are clear-cut signals of a looming fiscal crisis. Since most of the borrowings are money from banks or the inter-bank market, the looming fiscal crisis has already spread over to financial risks in the banking sector. The banking sector has already accumulated a relatively high non-performing loan (NPL) rate because of local government debt financing. However, the NPLs are mainly hidden behind new loans after loan restructuring. The whole process is a dangerous trip toward a fatal collapse of the financial system.

Chinese economic growth has slowed since 2011. Given the high level of local government debt, the new leadership has distanced itself from launching a new stimulus package that would lead almost inevitably to a fiscal and financial crisis. In addition, the real level of existing local government debt still needs to be clarified and it is a ticking time bomb. That is why the National Audit Office, in August 2013, started a new round of audits of local government debt, aimed at thoroughly checking on the local debt situation. 


\section{Overall Management and Characteristics of Urban Investment Bonds and Local Government Bonds in China}

As shown in Table 1, local governments currently use mainly bank capital in their deficit financing, while urban investment bonds and local government bonds are secondary. However, urban investment bonds and local government bonds deserve special attention since bond issuance and management are essential to ensure transparency of local government debt, if bonds are standardized and become their major debt financing channel.

Municipal bonds are a common, internationally accepted method of issuing local government debt. This kind of debt instrument is not limited to municipal governments and includes bonds issued by all levels of government below the national level. In general, municipal bonds cannot be used to cover regular budgetary deficits of local governments and can only be used for specific purposes. First, they are used to make up for differences in tax revenue and expenditure or to resolve problems caused by temporary fiscal operations. Second, they are used to provide financial support for various public capital investment programmes such as the maintenance of public works, building of schools, water drainage systems, etc. Third, they are used to support and subsidize programmes that spur local development and improve the lives of local residents, including the building of industrial parks, parking lots, etc. (Fisher 1996).

In a broad sense, municipal bonds refer to bonds issued by local governments or other authorized agencies and guaranteed by local governments. Funds collected are mainly used for the construction of local public infrastructure. In mature economies such as the United States, municipal bonds usually have four specific characteristics (Ba and Xing 2009): they are issued by the local government or an authorized agency thereof; the collected funds are used for the construction of public infrastructure at the municipal/local level; there is a diverse range of sources for repayment; and they enjoy special tax-free exemptions.

It is necessary to compare urban investment bonds and local government bonds with the standard municipal bonds in the world and look into the features of these two kinds of Chinese 'municipal bonds'.

\section{Urban Investment Bonds}

Urban investment bonds are issued as enterprise bonds by financing vehicle companies that are owned or controlled by local governments 
in China. The first such company was founded in 1992 in Shanghai city, and the first urban investment bond was issued by a financing vehicle company in Chongqing city in 2012. In the period 2008-2012, the total amount of urban investment bonds issued was around RMB 1.36 billion (see Figure 4). They basically meet the standards for municipal bonds, but are not tax free. In this regard, urban investment bonds can be regarded as 'quasi municipal bonds'. The funds raised are used for the building of public infrastructure. In this regard, the financing vehicle companies are in fact similar to subordinate departments of local governments, companies in which they have controlling shares or agencies of local governments. Local governments also provide them with hidden guarantees. Therefore, local governments and financing vehicle companies can be regarded as a single entity with mutual obligations.

Urban investment bonds are transacted in the interbank debt market. The explosion of urban investment bonds is related to the increasing rate of urbanization and even more so to the demand of local governments for the expansion of their spending in the face of global financial crisis. Urban investment bonds issued in 2009 totalled RMB 159.2 billion, while the amount issued in 2012 reached a record high of RMB 646.79 billion (Figure 4).

FIGURE 4: Amount of Newly Issued Urban Investment Bonds in China (2008-2012)

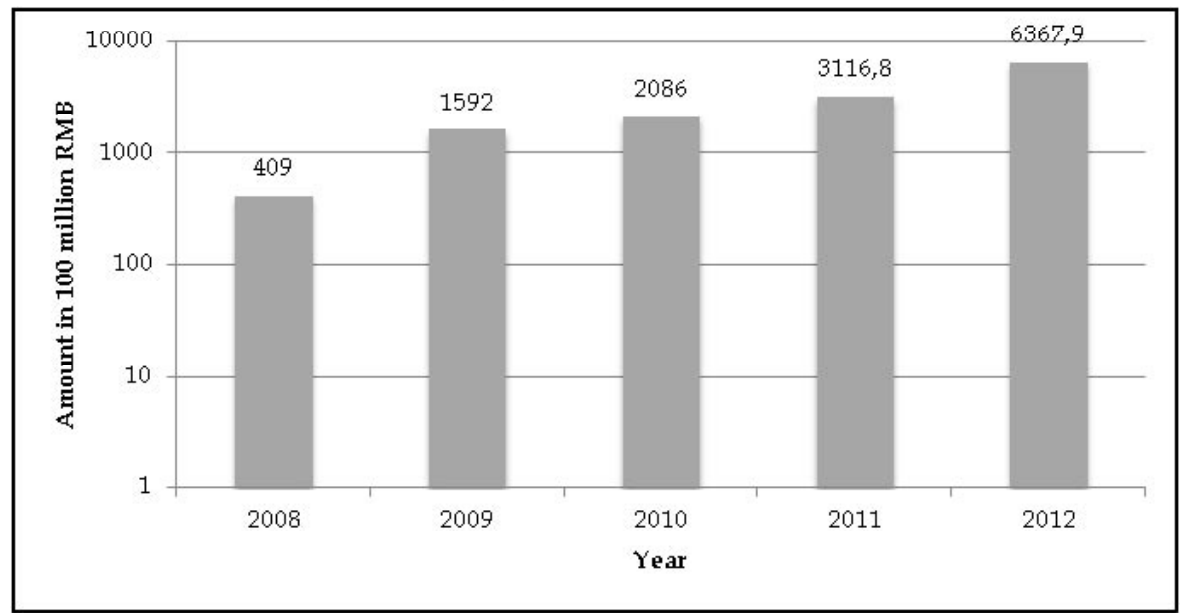

Sources: Zhao (2010); China Industry Research Net (2012); Zhang (2013); Yang (2013).

The operation of the urban investment bonds has the following general characteristics:

1. They are issued by financing vehicle companies, which are in fact issuing them on behalf of the local government; 
2. While urban investment bonds are issued as enterprise bonds, they actually function as municipal bonds;

3. Local governments provide hidden guarantees, which means that if there is the risk of defaulting, the local government will step in and provide assistance and bailouts;

4. The cost of financing is higher than the average level for enterprise bonds. According to research by He and Man (2011), the average coupon rate for bonds issued by financing vehicle companies from 2006 to 2009 was 5.72 per cent, while the rate for enterprise bonds of the same period was 5.63 per cent. The explanation for this is that the higher cost of financing for urban investment bonds reflected the market actors' concern about risk;

5. The capital brought in by financing vehicle companies is generally used by local governments for public infrastructure projects and the company itself is not actually obligated to repay the debt. The party responsible for repayment is the work unit or the local government to which it belongs;

6. Urban investment bonds and the entities that issue them are not subject to local democratic processes;

7. Because the debt owed by local governments is generally rather large, the risk of defaulting is also high. This makes the risk of defaulting on urban investment bonds also relatively high.

\section{Local Government Bonds}

The experiment with the issuance of local government bonds started in 2009. The total balance of local government bonds was RMB 650 billion at the end of 2012, which makes up only 2.6 per cent of the total debt of local governments in China. Most local government bonds are issued by the Ministry of Finance on behalf of local governments. The Ministry charged an issuance fee at a rate of 0.5 per cent and 1.0 per cent of the face value of the bonds issued in 2012. Only Shanghai, Zhejiang, Guangdong and Shenzhen are part of a trial self-issuing pilot programme begun in 2012. The government bonds issued by trial provinces or cities are fixed-rate bonds with a term structure of three years or five years and made up 50 per cent of all bond issuances approved by the State Council. Local governments below these levels of government do not have access to this financing instrument. But the provinces or cities that receive funds through the above issuance of local government bonds are allowed to on-lend the funds to lower level of governments. All of the local government bonds are to be repaid by the Ministry on behalf 
of these local governments. It is obvious that local governments lack local autonomy and local democracy in the whole process, which make them only 'quasi municipal bonds'.

The central government is still in control of any payment crisis that may result from its issuing these bonds on behalf of local governments or issuing them by local governments themselves since the central government itself is in charge of repayment on behalf of all the relevant local governments.

The major characteristics of local government bonds are as follows:

1. The introduction of local government bonds used a central government 'top-down' format, but its motivation comes from local governments' need to issue bonds. The Ministry of Finance has played a key role in this area;

2. The central government emphasizes that it is acting as an agent to control the risk of bonds and ensure against default;

3. The amount of bonds that can be issued has been increasing, but is still limited. It has increased from RMB 200 billion in 2009 to RMB 350 billion in 2013;

4. Currently, only provincial level governments and Shenzhen as a special economic zone are allowed to issue local government bonds directly. However, the issuance has not been extended to all levels of local government, including the various levels of government under them;

5. The overall operations lack local autonomy and local democracy. However, it will be difficult to use the current top-down control mechanism as a springboard to true municipal bonds. Local democracy is needed to turn this kind of bond into true municipal bonds.

\section{Framework of Rules for Local Government Debts and Bond Issuance}

As the local governments' debts have been mounting to a critical level since 2008, increasing local fiscal transparency and restricting local governments' behaviour has also become a necessity. Management of revenue and expenditure, including the power to issue debt for financing, is one of the competencies that local governments should have under the tax sharing system. Local government debts are a reality and the causes are complex. Simply forbidding local governments to raise debts by issuing debt bonds, or not giving local governments full status to issue 
and repay their own debt bonds, will not effectively stop local governments from collecting fees and raising debts in other ways. Quite the opposite, it will push these fee collections and debt financing activities out of the formal fiscal system, not only breeding illegal practices, but also threatening financial stability and China's macroeconomic balance. Allowing and standardizing taxation and debt financing, including the issuing by local governments of municipal bonds, is the only way to solve current problems at their root.

Allowing local governments to issue municipal bonds simply requires clear limits on use and supervision. Once a certain scale is reached and it is cost effective, this is the most effective way to legalize current local government debt practices and make them more transparent and standardized. To a great extent, not only will this relieve the fiscal pressure felt by local governments, it will also allow China's strict bond regulation system to make these types of programmes more transparent and standardized (An and Wang 2000; Gu 2000; Wei 2004; Xu 2001). As the content of this paper does not cover the entire debt issuing system, we simply attempted to analyse what has been said thus far and listed a few of the major problems facing local governments' bond issuance. Based on this, we can now propose basic policies from a constitutional and regulatory perspective. The main focus will be on clarifying the whole necessary institutional framework and local government responsibilities, and strengthening rule-based constraints, thus preventing uncontrolled expansion of local debts to which no one is held accountable.

1. A proper political reform is needed to constrain local government behaviour. This would consist of:

Enforcement of a constitutional reform and public participation. The constitution, fiscal constitution or any other basic law should clearly stipulate the power of local governments to manage public affairs, collect taxes and arrange expenditures. This will strengthen the sense of responsibility that governments feel to the people within their jurisdiction. In terms of municipal bond issuance and other fiscal decision-making processes, it will strengthen channels through which the public can participate. When organizing funding for and implementation of major municipal construction projects, it may also be advisable to have a referendum or hearing on the matter. Introduction of local autonomy and democracy. This can help standardize the handling of local government debts, urban investment bonds and local government bonds. It can force local governments to arrange their expenditure based on local citizens' preferences and the 
competencies of local governments. They can then raise funds based on need, through both taxation and debt issuance. Local autonomy refers to self-determination and self-governance by local citizens in the provision of local public goods and services, which differs from any idea of political independence or separation.

2. Strict rules of fiscal surveillance, auditing and supervision should be established and followed:

Strengthening fiscal surveillance. The core of the current problem is the uncontrolled expansion of local government debt, which may also be the biggest risk of allowing local governments to openly issue debts. Even if a number of measures could be conceived of to hedge this type of risk, the best policies must also have clear debt ceilings for each level of government at a higher legal level (ideally at the constitutional level). An example of this would be the local setting of upper limits based on the ratio of local government debt to local GDP or local fiscal revenue (these upper limits could be further divided into those for an emergency and general situations within the respective jurisdictions).

Auditing and supervisory regulation. Strict accounting procedures and standardized accounting records should also be put into place to allow for independent fiscal audits. There is also a need for a national committee to develop regulations on municipal bonds that place limits on the actions of local governments. These regulations would also deal with the underwriting of municipal bonds, broker-dealers and banks. ${ }^{14}$

3. A set of concrete fiscal rules for local government debt financing, including municipal bond issuance, should be established and enforced:

Uses of municipal bonds and reasons for their issuance. Considering the lack of standardization in the operations of local governments in China as well as their wide range of responsibilities, it is necessary to strictly limit the uses of municipal bonds and the reasons for their issuance, especially in issuing bonds to balance budget deficits. One possibility is the establishment of conditions for bond issuance, allowing local governments to issue bonds only if the overall debt levels and the budget deficits are kept within a certain range, for instance, for three consecutive years. Furthermore, authorization to issue bonds would be revoked for the following fiscal year should the government incur a large fiscal deficit. In considering the difficulty of external supervision and the possibility of local governments 
deliberately using funds for other purposes, one option when first issuing municipal bonds could be to only allow local governments to issue revenue bonds with clear-use purposes (as in the building of a local roadway) instead of general obligation bonds. As local democratic fiscal procedures improve, this could be relaxed to include general obligation bonds.

Debt issuing entities and procedures. To change the current chaos of governments, their various departments and even companies or public service units under their charge (such as public schools and hospitals), so that debt raising is predictable and transparent, only a single or relatively limited number of specified entities would be authorized to issue debt (i.e. government financial departments). Procedures for issuing debt must be standardized by law, including methods for application, approval, credit rating, commissioned agencies and public placement. The forced proportional distribution of debt must also be prohibited. Purchasing qualifications should also be more closely controlled, prohibiting administrative work units and companies with a certain portion of state-owned assets from purchasing, to prevent covert proportional distribution.

Internal controls and external supervision. Due to the difficulty of quickly establishing a democratic system that can respond to the preferences of local residents in the short term, a plausible option for internal control is to strengthen the power of the local people's congress. Requirements can be put in place that a single bond or a series of bonds to be used for a specific project of a certain scale must go through hearings and be approved by the people's congress (and consultative committee). External supervision is usually carried out by financial authorities, but as a transitional measure, the supervisory powers of higher levels of government and the people's congress could be strengthened. This can be done in such a way that local debt issuances above a certain scale must be approved by a higher level of government or the people's congress, based on a minimum standard. They can also be required to submit periodic reports on the state of the debt, its market price and efficiency.

Procedures for passing on debt to new administrations. When a new administration comes in or major officials are replaced, a major audit of debt must be carried out. The scale of the debt issued during a term and the efficiency of its use during a certain period of time after that term has ended should be included in the evaluation of the Party or government official in office when the debt was issued. 
This could, to a certain extent, prevent excessive debt due to shortsightedness.

Repayment of Debt. To ensure that the principal and interest on debt is paid in a timely manner, a repayment fund should be established that holds a portion of revenue periodically placed in the fund from projects funded by municipal bonds. An order of priority for sources of loan repayment should also be established, setting a ceiling and ratio for the amount of tax revenue to be used for their repayment. Laws should also be passed that clearly define under what financial circumstances or what kind of revenue situation for a specific project constitutes a payment crisis. This could prevent local governments from deliberately not paying debts. Currently, government bankruptcy is not a feasible option (this would increase the moral risk that governments face). One option may be to extend payment periods or allow governments to make partial payments, which would eliminate the idea that a government will get off on a fluke. This would leave some risk in place and prevent investors from ignoring risk and investing too much.

Joint responsibility between governments. Currently, lower levels of government are generally responsible to higher levels of government. It must be clarified what debts and in what situations higher levels of government would take on what portion of debt responsibility for lower governments. This would prevent lower levels of government from making opportunistic decisions. Similarly, it must be clarified what portion of debt responsibility lower levels of government have when issuing municipal bonds through higher levels of government. This will keep higher levels of government from improperly using administrative powers to transfer debt responsibilities.

Clarification of borders between fiscal behaviour and financial market behaviour of local governments. It should be taken into account that local governments may very well try to obtain capital through banks. Since local governments have the power to interfere directly or indirectly in the affairs of local banking institutions or the local branches of banking institutions operating nation-wide, ${ }^{15}$ a clear line must be drawn between the employment of different types of financial instruments, such as municipal bonds, and bank loans. Whether in terms of underwriting loans, purchasing, transacting or repaying loans, governments must not be allowed to directly or indirectly use capital from lending organizations to repay municipal bonds. However, this does not preclude lending organizations 
from participating in the above-mentioned processes. Limitations on participation of lending organizations can be adjusted based on the direct or indirect interference of local governments, allowing for them to be tightened, relaxed or removed altogether.

Development and supervision of secondary market of municipal bonds. After a large-scale issuance of municipal bonds, it may be necessary to establish a market for municipal bonds in secondary markets, including national, regional and local over-the-counter markets.

Standardization of historical debts and linking them to new debts. As nearly all levels of government have some debt burden and a large portion of that is unrecoverable, the need by local governments to issue new debts to repay old debts is especially urgent. Before local democratic procedures are introduced, if there are no essential fiscal restrictions on local liabilities, such as setting an upper limit ratio of local GDP to fiscal revenue, laws must be put into place to strictly prohibit refinancing by issuing new municipal bonds. If this kind of restriction is put into place, prohibiting the refinancing would be unnecessary. In any case, there must be certain restrictions in place on new debts for a single project. The best option would be to put procedures in place for the approval of new debt financing of the same projects that require a certain portion of the previous debts to be paid off and revenue from these projects to have reached a certain level before new debts can be incurred. ${ }^{16}$

\section{Concluding Remarks}

The above-mentioned problems are only a major part of the problems with local government debt financing and bond issuance. There are no doubt many that have not been included. However, the key problem is that while we do support a standardized system that allows for local government liabilities as a channel for financing of local governments in China, it must be emphasized that municipal bonds alone cannot resolve the root of these problems. If this is not handled properly, it may result in a negative outcome. The most obvious example of this is China's stock market, where a few investors profited greatly and the vast majority of opportunistic investors lost out. The problem of low efficiency of state-owned enterprises was not resolved through the establishment of the stock market. From a wider historical perspective, it actually delayed the resolution of the root problem because of constant blood transfusions. 
There are similar problems present in local government debt. Only a very small part of the problem of local government debt in China can be traced back to the public goods nature of some goods and services that local governments provide. Most problems of local government debt are connected to the lack of constitutional and fiscal rules constraining the central government and local governments, the absence of local democracy, the pressure of fiscal competition and economic performance in individual regions, the over-investment and excessive construction connected with it, the repercussions of fiscal reforms since 1994 that resulted in the centralization of fiscal revenue, and the haphazard changes in the terms of officials at higher levels of government. None of these problems can be resolved by simply issuing municipal bonds. Allowing issuance of municipal bonds is an opportunity that could bring these problems to the debate table and see resolution as the framework that manages municipal bonds is perfected. If issuing municipal bonds has ultimately only given local governments another vehicle to legally make money and higher levels of government more of an opportunity to push their responsibilities downward and gain more fiscal power, then not only will these problems go unresolved, the issue of local debts will most likely become increasingly serious and ultimately irreparable. As this article has tried to express, which of these two futures is chosen will fully depend on establishing a framework of rules and properly implementing those rules.

Feng Xingyuan is Professor of Rural Development Institute of China Academy of Social Sciences, and Vice Director of the Unirule Institute of Economics. E-Mail:fengxy@cass.org.cn.

\section{NOTES}

1 In this article, all levels of government below the national level are regarded as 'local'.

2 According to Breton (1996), the 'competitive governments' paradigm refers to the fact that there is inter-, intra- and extra-governmental competition in federations such as the USA and Canada, while according to Levitsky and Way (2013: 5), the 'competitive authoritarianism' paradigm refers to regimes that 'are civilian regimes in which formal democratic institutions are widely viewed as the primary means of gaining power, but in which fraud, civil liberties violations, and abuse of state and media resources so skew the playing field that the regime cannot be labeled democratic'. Both paradigms stress the self-interest-driven competition of governments as a key feature that drives the political life in relevant countries. However, the competitive nature of a multi-layer government system doesn't only exist in real democracies 
or authoritarian quasi-democracies, but also in a formally unitary system such as the Chinese one. That is why it makes sense to extend the use of such paradigms to the Chinese system.

3 For the typical features of a 'leviathan', see Hobbes (1651) and Brennan and Buchanan (1980).

4 In the following, the terms 'urban investment bonds' and 'local government bonds' refer to these two concrete types of bonds.

5 System-external revenue, or 'zhidu wai shouru', consists of illegal levies imposed by local governments upon the economy. They include 'arbitrary fund raising, arbitrary fee charging, and arbitrary cost apportion' (called 'san luan' in Chinese) by local governments.

6 These 36 local governments audited by the National Audit Office (2013) are governments of 15 provinces and those of their 15 respective capital cities, and governments of 3 municipalities under direct administration by the central government and those of their 3 districts. The narrowly defined debt balance of their vehicle companies and the debt balance of local government departments and institutions took 45.67 per cent and 25.37 per cent of their total debt balance at the end of 2012, respectively. In the audit report, all data refer only to the individual levels of local government and do not encompass the lower levels of local government. This applies in the following part of this article.

7 Local pension funds in many jurisdictions often run on almost empty or half-empty accounts. Funds are often diverted by local governments for other uses. They also do not pay in sufficient funds for employees from the public sector or local state-owned enterprises. This hidden debt is related to the amount that local governments have to inject into the pension funds to pay pensions as required by the law (Wang 2013).

8 The People's Bank of China and China Banking Regulatory Commission on $18 \mathrm{March}$ 2009 jointly released 'Guiding Opinions on Further Strengthening the Adjustment of the Loan Structure to Push Forward a Stable and Relatively Rapid Development of the National Economy' to encourage local governments to establish local financing vehicle companies.

9 Already on 10 June 2010, the State Council issued a 'Notice on Problems Related to the Strengthening of the Management of Local Government Financing Vehicle Companies' (Document No. guofa (2010) 19) and ordered debt financing of vehicle companies to be put in order and the management of these companies strengthened. The National Audit Office conducted a wide-scale survey of the debt of local financing vehicle companies, starting at the end of 2010 and released a report on 'Audit Results on Local Government Debt in the Whole Country' (Report No. (2011) 35) on 27 June 2011. The report revealed the audit results on local governments' debt financing across China. Later on, various notices of the National Development and Reform Commission, People's Bank of China, China Banking Regulatory Commission, and Ministry of Finance, Ministry of Land were issued, strengthening the control of loan disbursements and debt issuance, restriction of the qualification as vehicle companies, restrictions on using land transfer revenue as a pledge, prohibition of false capital registration and under-collateralization, etc.

10 The storm surrounding the default of Yunnan Province Roads Development Co., Ltd. ('Yunnan Roads') on its loans is a perfect example and marked the start of the vehicle company debt crisis. It is a vehicle company associated with the government of Yunnan province. In April 2011, Yunnan Roads issued a letter to the bank lender saying that they would pay only the interest and not the principle. Yunnan Roads had nearly RMB 100 billion in loans from more than ten banks including the China Construction Bank, the National Development Bank and ICBC (Shi 2012). After the 
debt problem became known, the company retracted the letter on the advice of the provincial government, which then came out to discuss repayment of the loans in the company's place and avoided an all-out crisis. However, the scare of default sent unexpected shock waves through the urban investment bond market and new bonds were not issued for a period of time afterwards.

11 Local party or government leaders are first nominated within the Party or the administration, examined by the organizational department of the party secretariat at the local and the next higher level, and finally approved by the next higher level of the party secretariat after the ceremonial or ritual 'elections' through the local party congress or local people's congress, respectively. The core principle is that the cadres are to be led by the Party according to the CCP's 'Regulation on the Selection and Appointment of Party and Government Leaders' of 23 July 2002.

12 See Zhou (2007). Zhou's analysis shows that the close connections of the career of local government leaders to local economic performance constitutes a strong positive incentive for these leaders to promote local economic development.

13 Some provinces, for instance Guangdong province, in 2012 started with the change of performance criteria for local leaders, to include other criteria such as the improvement of economic structure, the reduction of resource use per unit of GDP, environmental protection, autonomous innovations, coverage of public services for the migrant population, etc. However, economic performance is still a key criterion. Only in non-development zones where economic activities are in general forbidden, is economic performance no longer a criterion in that province (Chen and $\mathrm{Wu}$ 2012).

14 Here we can learn from the experience of the United States. In 1975, the United States established the Municipal Securities Rulemaking Board, which was responsible for creating rules that regulated broker-dealers and banks.

15 For example, the current practice of local banking institutions such as rural credit cooperatives, requiring an endorsement from the local party committee to put in or remove management from their positions provides a route for local government interference.

16 This suggestion is based on lessons from the improper operation of China's stock markets. Many of the listed companies on China's stock exchanges used allotments or extensions to collect a large amount of capital from small investors. Regulations limiting this type of practice only came into effect recently.

\section{REFERENCES}

An, Yikuan, and Wang Zhiyu 2000. 'Using Municipal Bonds to Drive the Construction of Urban Infrastructure', China Investment 9: 18-20.

Ba, Shusong, and Xing Yujing 2009. 'From Urban Investment Bonds to Municipal Bonds: The experience of mature markets', Guandian Net, 24 November. Available at: http://www.guandian.cn/article/20091124/88952.html (in Chinese); accessed 29 November 2013.

Brennan, Geoffrey, and James. M. Buchanan 1980. The Power to Tax: Analytical Foundations of a Fiscal Constitution. Cambridge: Cambridge University Press.

Brennan, Geoffrey, and James M. Buchanan 1985. The Reason of Rules: Constitutional Political Economy. Cambridge and New York: Cambridge University Press.

Breton, Albert 1996. Competitive Governments: An Economic Theory of Politics and Public Finance. New York: Cambridge University Press.

Cao, Jinling 2013. 'Withdraw the Hidden Debt Guarantees is a Pressing Matter', China 
Business News, 12 July.

Chen, Hanhui, and Zhe Wu 2012. 'Guangdong Said Good Bye to "GDPism" and Enforced Different Performance Criteria for Different Zones'. Enorth Net, 16 November. Available at: http:/ / news.enorth.com.cn/system/2012/11/06/010237423.shtml (in Chinese), accessed 25 October 2013.

China Industry Research Net 2012. 'A Survey on the Development of the Market of Urban Investment Bonds in 2012', 25 December. Available at: http:/ / www.chinairn. com/news/20121225/524868.html, accessed 28 May 2013.

China Urban and Rural Finance Daily 2012. 'The Amount of Policy Finance Bonds Issued This Year Will Exceed RMB 2 Trillion', 24 December. Available at: http:/ / www.howbuy.com/news/2012-12-24/1778051.html (in Chinese), accessed 27 May 2013.

Dong, Yunfeng 2012. 'Local Financing Vehicle Companies Switched to Targeted Instruments Aiming at Fundraising With "Big Stomach"'. China Business News, 23 August.

Fan, Liming, Qiyun Li, et al. 2001. Analysis of Local Fiscal Practices in China. Beijing: Economic Sciences Press.

Feng, Xingyuan 2010. Local Government Competition. Nanjing: Yilin Press.

Feng, Xingyuan, and Xiaojia Li 2005. 'Debts of Municipal Governments and Framework of Order for Municipal Bonds'. Management World 3: 29-42.

Fisher, Ronald C. 1996. State and Local Public Finance, 2nd ed. Chicago: Richard D. Irwin, Inc.

Gu, Huizhong 2000. 'Local Government: How Big is the Debt Risk?' Voice of Reform 5: 31-33.

He, Yang, and Yanyun Man 2011. 'Local Debt Scale in China and an Analysis of its Risk'. Working Paper of Peking University-Lincoln Institute Urban Development and Land Policy Research Center, No. W093, October.

Herrmann-Pillath, Carsten 1999. 'Die fiskalische und regionale Dimension des systemischen Wandels großer Länder: Regierungswettbewerb in China und Rußland'. Diskussionspapier, Fakultät für Wirtschaftswissenschaft der Universität Witten/Herdecke, Heft 42, September.

Herrmann-Pillath, Carsten, and Xingyuan Feng 2004. 'Competitive Governments, Fiscal Arrangements, and the Provision of Local Public Infrastructure in China: A Theory-driven Study of Gujiao Municipality'. China Information 18 (3): 373-428.

Hobbes, Thomas 1651/1969. Leviathan. London: Scolar Press.

International Monetary Fund 2013. 'China: Explaining "Augmented" Government Debt and Deficit'. Available at: www.imf.org/external/np/sec/pr/2013/pdf/pr13192an. pdf, accessed 29 November 2013.

Jin, Hehui, Yingyi Qian, and Barry Weingast 2005. 'Regional Decentralization and Fiscal Incentives: Federalism, Chinese Style'. Journal of Public Economics 89 (9-10): 1719-1742.

Levitsky, Steven, and Lucan A. Way 2013. Competitive Authoritarianism. Hybrid Regimes After the Cold War. Cambridge: Cambridge University Press.

Li, Shanghong 2000. 'Examination of Problems in Local Government Debt'. Exploring Economic Issues 7: 55-57.

$\mathrm{Li}$, Shaomin, Shuhe Li and Weiying Zhang 1998. 'Cross-regional Competition and Privatisation in China'. MOST: Economic Policy in Transitional Economies 9 (1): 75-88.

Li, Yuequn 2011. Local Governments' Debt Ratios Are Too High: Be Cautious of the Outbreak of the High Tide of Bad Debt, China News Service, 16 September.

Li, Yumin 2013. 'Urban Investment Bonds Were Issued in an Immense Amount in 2012 and the Possibility of the Outbreak of a Crisis Is Increasing'. National Business Daily, 7 January. 
Lu, Xinjie 2012. 'A Study on the Problems of Local Government Financing Vehicle Companies in China' (Dissertation). Chengdu: Southwestern University of Finance and Economics.

National Audit Office 2011. Audit Results on Local Government Debt in the Whole Country, 2011 Audit Report No. 35, 2011.

National Audit Office 2013. Audit Results on the Debt of Local Governments of 36 Local Jurisdictions, Audit Report No. 24, 2013.

Netease Finance 2013a. 'China Banking Regulatory Commission: The Balance of Loans of Local Government Financing Vehicle Companies Reaches RMB 9.2 Trillion', 29 January. Available at: http:/ / money.163.com/13/0129/17/8MDF79KV00253B0H. html (in Chinese), accessed 28 May 2013.

Netease Finance 2013b. 'The Former Ministry of Railways Realized a Profit of RMB 196 Million While Held a Debt of RMB 2.79 Trillion', 27 April. Available at: http:/ / money.163. com/13/0427/16/8TFSS4QK002526O5.html (in Chinese), accessed 27 May 2013.

Nie, Ou 2013. 'Local Financing Vehicle Companies Slam a Hard Brake on Debt Raising'. Business and Economy Weekly, 12 April.

Research Team of the Project on Problems with County and Township Level Government Finance in China 2005. Report on Problems with County and Township Level Government Finance in China. Beijing: Academy of Macroeconomic Research of National Development and Reform Commission.

Shi, Jinfeng 2012. 'A Year after Defaulting, "Yunnan Roads" Is Back in Business'. 21st Century Business Herald, 22 November. Available at: http:/ / author.21cbh.com/shijinfeng, accessed 6 May 2013.

Shi, Jinfeng 2013. 'The New Policy of Classifying On- and Off-sheet Businesses is Targeting the Financing Problems of Financing Vehicle Companies and the Real Estate Sector: The CBRC Announced Its Active Support for Investment in Key Projects in Railways, Roads and New Industries'. 21st Century Business Herald, 29 January.

Shen, Yubiao 2010. 'China's Population Expected to Reach 1.5 billion by 2030, Balanced Development Essential'. China Broadcast Net, 23 October. Available at: http:/ / www. cnr.cn/allnews/201010/t20101023_507212692.html, accessed May 202013.

Standard Chartered 2013. 'Asia Leverage Uncovered', 1 July.

Sun, Qing 2013. 'Local Financing Vehicle Companies Got Implicitly Connected to Oversee Funds, With Microcredit Companies Acting as Intermediaries'. China Business News, 1 June.

Wang, Mei 2013. 'About the Debt Size of Local Financing Vehicle Companies: The Difference between the Reports of the National Auditing Office and the China Banking Regulatory Commission'. China Business News, 30 May.

Wang, Xiaohui 2012. 'The Unification of Different Pension Systems is Not Included in the Reform of the Income Redistribution System and the Ratio of Empty Accounts is High'. Huaxia Times, 3 November.

Wei, Jianing 2004. 'Debt and Financial Risk in Local Government in China'. Commercial Weekly, 5.

$\mathrm{Xu}$, Shijie 2001. 'Municipal Bonds in the United States and Inspiration'. China Investment, 7.

Xu, Tiaoxiao 2013. 'Trust Borrowing for Investment in Real Estate Is Boosting Up Only More Than One Month After the Rough Assessment of Local Government Debt through Auditing'. Securities Daily, 6 September.

Yang, Qianwen 2013. 'Moody: The Trend of the Increase in Local Government Debt Will be Reversed with the Gradual Increase in Default Risks'. China Business News, 20 March.

Yang, Y., and L. Wu 2013. 'SASAC Warns of Risks of Local Financing Vehicle Com- 
panies, With a Debt Size Amounting to RMB 13 Trillion by End 2013'. Economic Information Daily, 22 January.

Yu, Bing, and Jianing Wei 2012. A Study on Fiscal and Financial Risks in China. Beijing: China Development Press.

Zhang, Taixin 2013. 'The Net Increase of the Amount of Urban Investment Bonds May Reach RMB 1 Trillion'. China Securities Journal, 20 March.

Zhao, Xu 2010. 'Rapid Increase of New Issuance of Local Enterprise Bonds with Rise of Medium and Small Scale Securities Dealers'. Shanghai Securities News, 4 January.

Zheng, Chunrong 2012. 'The Real Risks of Local Government Debts in China: Risks Beyond the Default Risks'. Public Administration Review 4: 52-76, 179-180.

Zhou, Li'an 2004. 'Incentive and Cooperation among Chinese Officials in an Increasingly Intense Game - Discussing Local Protectionism in China and the Reasons for Continued Re-construction'. Economic Research Journal 6: 33-40.

Zhou, Li'an 2007. 'A Study on the Model of the Career-centered Economic Championship Contest of Local Government Officials in China'. Journal of Economic Research 7: 36-50. 